\title{
Determination of molecular weights of biologically active fragments of colostrum by electrophoresis method
}

\author{
Inna Lych ${ }^{1}$, Serhii Veriovka ${ }^{2}$, Anna Zayarnyuk ${ }^{1}$
}

1- National University of Food Technologies, Kyiv, Ukraine

2 - National Academy of Medical Sciences of Ukraine prof. O.S. Kolomiychenko Institute of otolaryngology, Kyiv, Ukraine

Keywords:

Colostrum

Protein

Immunoglobulin

electrophoresi

Immunity

\section{Article history:}

Received 14.09.2017

Received in revised

form 26.11.2017

Accepted 29.12.2017

\section{Corresponding author:}

Inna Lych

E-mail:

innalych78@

gmail.com

DOI: $10.24263 / 2310-$

1008-2017-5-2-4

\section{Abstract}

Introduction. The objective of the present article is to determine the molecular weights of the protein mixture of the cow colostrum. This will lead to the development and production of immuno-prophylactic products for maintaining immunity human body.

Materials and methods. Bovine milk was the main material for the study. The test samples have been selected from the first day of calving and during the following three days. Specimen 1 represented the colostrum of the cows from Zhytomyr region (Berdychiv town). Specimen 2 represented the bovine colostrum from Kyiv region (Tetiiv town). Electrophoresis method in the polyacrylamide gel in the Laemmli system.

Results. It has been determined that high molecular weight fractions of colostrum contain protein molecules with molecular weights of $160-190 \mathrm{kDa}$, among which are immunoglobulins. Separate parts of immunoglobulins and other proteins, namely, IgG $(55 \mathrm{kDa})$ and $\operatorname{IgA}(62 \mathrm{kDa})$ heavy chains, secretory component of sIgA, and lactoferrin, have also been found out.

The test samples of high molecular weight peptides of colostrum contain the biologically active fragments among which there are mostly immunoglobulins, their parts, proteinsabzymes, other protein fragments. The proteins with the molecular weight of $80,62,55 \mathrm{kDa}$ are also determined, they can represent heavy chains $(55 \mathrm{kDa})$ and light chains $(25 \mathrm{kDa})$ of $\operatorname{IgG}$ and $\mathrm{sIgA}$. In particular, $\operatorname{sg} \mathrm{A}$ is a supermolecular complex consisting of $\mathrm{H}$ - and L-chains of $\operatorname{IgA}(62,25 \mathrm{kDa}$, respectively) and a secretory component $(80 \mathrm{kDa})$. Apart from the secretory component of $\operatorname{IgA}$, the protein molecules with the molecular weight of $80 \mathrm{kDa}$ can be halves of the molecules of immunoglobulins or lactoferrin.

Conclusion. The presence of a large quantity of proteins allow using the colostrum in the production of childhood, functional, medical, and prophylactic nutrition; in biotechnologies for the manufacturing of other food products with a special composition; in medicine and pharmacology to produce food-grade coats and capsules for medical substances, dietary food supplements. 


\section{Introduction}

Studying the interrelation between the immune response and nourishment is one of the actual issues as it allows determining the possible reasons of the development of immune deficiency states in a human organism. The main role of nutrition is in a trophic, plastic, and energy support of the functional activity of the body, including the immune system. The components of food products show the immunomodulatory properties in terms of the acquired cell and humoral immunity, and nonspecific factors of the inborn immunity. It is known that the nutritional disorder also leads to the change of the operation of the immune system.

In this respect, the development of a balanced immune diet represents a new trend in the modern nutraceuticals. It has been proven that due to the consumption of nutraceuticals the increase of phagocytosis and bacterial activity of neutrophils is observed, as well as the growth of the general number of lymphocytes, activated T-lymphocytes, NK cells, and IgA, $\operatorname{IgM}, \operatorname{IgG}[1,11]$.

Cow colostrum is a well-known evolutionally balanced food product, because it contains all necessary components to maintain the active immunity and to renew and activate the weakened immune system.

Colostrum is vital for newborn calves. This is conditioned by the presence in its composition of a large number of the mother's antibodies that strengthen the immunity of a newborn calf and protect it from various disease producing microorganisms, which attack a calf's organism since the first months of its life $[2,10]$.

The digestive tract of newborn calves is characterized with high permeability enhancing the direct delivery of antibodies and different nutritive substances of colostrum to the blood flow. Besides, colostrum contains two times more dry substances, 100 times more vitamin A, and six times more protein, and 3 times more mineral substances than the ordinary milk [13].

Alongside with the advantages of the colostrum over the ordinary milk, there are a number of problems related to its storage and disposal. This is explained by the inability of the newborn calves to consume all the colostrum of the cows as its quantity exceeds the needs of the calves that consume only $30-50 \%$ of the total quantity of colostrum [3]. Due to its physical and chemical properties, the excess of colostrum cannot be used to produce dairy products. It has a thick consistency, salty taste, and specific smell, it coagulates during the thermal treatment. The dairy products produced from milk acquire an unpleasant taste and quickly spoil during storage even with the smallest addition of colostrum [4]. Therefore, the issues related to the processing of the excess of colostrum remain relevant.

\section{Materials and methods}

To extract and refine proteins, the test colostrum was divided into 2 test specimens.

The received colostrum samples from different regions have been distributed in the following way:

- Sample 1 - the bovine milk of Specimen 1, taken on the first day in two hours after calving;

- Sample 2 - the bovine milk of Specimen 1, taken on the first day in 12 hours after calving;

- $\quad$ Sample 3 - the bovine milk of Specimen 1, taken on the second day in 24 hours after calving; 
- $\quad$ Sample 4 - the bovine milk of Specimen 1, taken on the second day in 36 hours after calving;

- Sample 5 - the bovine milk of Specimen 1, taken on the third day in 48 hours after calving;

- Sample 6 - the bovine milk of Specimen 1, taken on the third day in 60 hours after calving;

- Sample 7 - the bovine milk of Specimen 2, taken on the first day in two hours after calving;

- Sample 8 - the bovine milk of Specimen 2, taken on the first day in 12 hours after calving;

- $\quad$ Sample 9 - the bovine milk of Specimen 2, taken on the second day in 24 hours after calving;

- Sample 10 - the bovine milk of Specimen 2, taken on the second day in 36 hours after calving;

- Sample 11 - the bovine milk of Specimen 2, taken on the third day in 48 hours after calving;

- Sample 12 - the bovine milk of Specimen 2, taken on the third day in 60 hours after calving;

-Sample 13 - milk (control).

Biologically active fragments of colostrum were obtained according to the diagram below, Figure 1 .

In the result of the gel filtration, two fractions have been obtained: the high molecular weight peptides and low molecular weight peptides of colostrum (Table 1).

Determination of molecular weights of the refined protein solutions of bovine colostrum and milk was carried out by the electrophoresis method in the polyacrylamide gel in the Laemmli system [5]. Electrophoresis was conducted by means of Hoefer apparatus (Amersham Biosciences, USA) with the current of $19 \mathrm{~mA}$ for the concentration gel and 36 $\mathrm{mA}$ for the separating gel $[6,12]$. PageRuler Plus Prestained Protein Ladder were used as markers with such proteins as $250 \mathrm{kDa}, 130 \mathrm{kDa}, 100 \mathrm{kDa}, 70 \mathrm{kDa}, 55 \mathrm{kDa}, 35 \mathrm{kDa}, 25$ $\mathrm{kDa}, 15 \mathrm{kDa}, 10 \mathrm{kDa}$ (Thermo Fisher Scientific, USA).

To prepare samples for the electrophoresis, the buffer for samples was added to the protein solution, which contained $5 \%$ of saccharose (for more thickness); $2 \%$ of SDS (for the decomposition of protein associates into separate polypeptide chains and change of the molecule charge into negative); bromophenol - before the colouring. The samples were heated in the water bath.

The colouring of the gel was carried out in the solution of $0,01 \%$ Coomassie G-250, in $25 \%$ isopropanol, and 10\% acetic acid during 10 minutes. To eliminate the remains of the colouring agent, $2-8 \%$ solution of acetic acid was used. The resolution of the method is 1 $\mu \mathrm{g}$ of protein. 


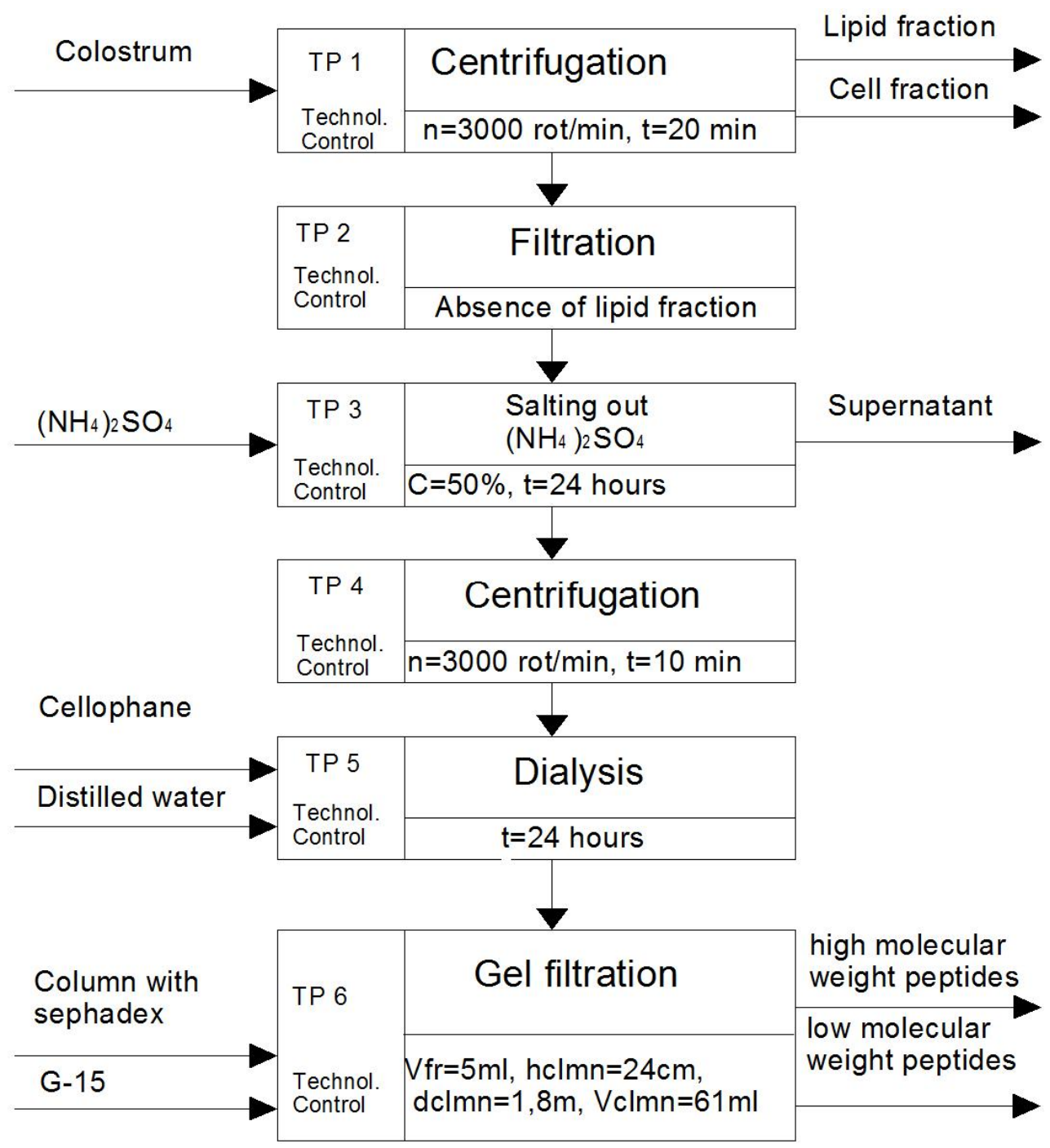

Figure 1. Diagram for the extraction and refinement of the milk and colostrum proteins 
Characteristic of the biologically active fragments of colostrum under study

\begin{tabular}{|c|c|c|}
\hline Name & Fraction No & Remark \\
\hline \multirow{2}{*}{$\begin{array}{l}\text { Sample 1: Day } 1 \text { in } 2 \text { hours } \\
\text { after calving (calving on } \\
10.02 .2016 \text { ) }\end{array}$} & 1 & high molecular weight peptides \\
\hline & 2 & low molecular weight peptides \\
\hline \multirow{2}{*}{$\begin{array}{l}\text { Sample 2: Day } 1 \text { in } 12 \text { hours } \\
\text { after calving (calving on } \\
10.02 .2016)\end{array}$} & 3 & high molecular weight peptides \\
\hline & 4 & low molecular weight peptides \\
\hline \multirow{2}{*}{$\begin{array}{l}\text { Sample 3: Day } 2 \text { in } 24 \text { hours } \\
\text { after calving (11.02.2016) }\end{array}$} & 5 & high molecular weight peptides \\
\hline & 6 & low molecular weight peptides \\
\hline \multirow{2}{*}{$\begin{array}{l}\text { Sample 4: Day } 2 \text { in } 36 \text { hours } \\
\text { after calving (11.02.2016) }\end{array}$} & 7 & high molecular weight peptides \\
\hline & 8 & low molecular weight peptides \\
\hline \multirow{2}{*}{$\begin{array}{l}\text { Sample 5: Day } 3 \text { in } 48 \text { hours } \\
\text { after calving }(12.02 .2016)\end{array}$} & 9 & high molecular weight peptides \\
\hline & 10 & low molecular weight peptides \\
\hline \multirow{2}{*}{$\begin{array}{l}\text { Sample 6: Day } 3 \text { in } 60 \text { hours } \\
\text { after calving }(12.02 .2016)\end{array}$} & 11 & high molecular weight peptides \\
\hline & 12 & low molecular weight peptides \\
\hline \multirow{2}{*}{$\begin{array}{l}\text { Sample 7: Day } 1 \text { in } 2 \text { hours } \\
\text { after calving (calving on } \\
21.01 .2016 \text { ) }\end{array}$} & 13 & high molecular weight peptides \\
\hline & 14 & low molecular weight peptides \\
\hline \multirow{2}{*}{$\begin{array}{l}\text { Sample 8: Day } 1 \text { in } 12 \text { hours } \\
\text { after calving (calving on } \\
21.01 .2016 \text { ) }\end{array}$} & 15 & high molecular weight peptides \\
\hline & 16 & low molecular weight peptides \\
\hline \multirow{2}{*}{$\begin{array}{l}\text { Sample 9: Day } 2 \text { in } 24 \text { hours } \\
\text { after calving }(22.01 .2016)\end{array}$} & 17 & high molecular weight peptides \\
\hline & 18 & low molecular weight peptides \\
\hline \multirow{2}{*}{$\begin{array}{l}\text { Sample 10: Day } 2 \text { in } 36 \\
\text { hours after calving } \\
(22.01 .2016)\end{array}$} & 19 & high molecular weight peptides \\
\hline & 20 & low molecular weight peptides \\
\hline \multirow{2}{*}{$\begin{array}{l}\text { Sample 11: Day } 3 \text { in } 48 \\
\text { hours after calving } \\
(23.01 .2016)\end{array}$} & 21 & high molecular weight peptides \\
\hline & 22 & low molecular weight peptides \\
\hline \multirow{2}{*}{$\begin{array}{l}\text { Sample 12: Day } 3 \text { in } 60 \\
\text { hours after calving } \\
(23.01 .2016)\end{array}$} & 23 & high molecular weight peptides \\
\hline & 24 & low molecular weight peptides \\
\hline \multirow[t]{2}{*}{ Sample 13. Reference (milk) } & 25 & high molecular weight peptides \\
\hline & 26 & low molecular weight peptides \\
\hline
\end{tabular}

\section{Results and discussion}

According to the classification of the Committee for nomenclature and methodology of milk proteins of the American Dairy Science Association, milk proteins are divided into caseins, the molecular weight of which is $14-22 \mathrm{kDa}$, and whey proteins [7]. Whey proteins comprise $\beta$-lactoglobulins and $\alpha$-lactoalbumins, the molecular weight of which is $\approx 18 \mathrm{kDa}$ and $14 \mathrm{kDa}$, respectively, also, lactoferrin $(80 \mathrm{kDa})$, lysozyme $(15 \mathrm{kDa})$, and immunoglobulins. 
The major classes of the secretion of the mammary gland of the cattle and human are IgM, IgG, IgA, IgE, IgD. The full major molecule of Ig has Y-like structure and molecular weight of about $160 \mathrm{kDa}[8,9]$.

$\mathrm{IgG}$ is a monomer, the molecular weight of which is $\approx 160 \mathrm{kDa}$. Isotype $\mathrm{G} 1$ represents the major weight of $\mathrm{Ig}$ as it contains $70-80 \%$ of all serum immunoglobulins. IgA is a monomer with the molecular weight of about $170 \mathrm{kDa}$. It contains approximately $10-15 \%$ of all serum Igs. This immunoglobulin also exits in the secretory form (sIgA). Secretory sIgA exits in the polymeric form like di- or trimer connected by J-chain $(15 \mathrm{kDa})$, it also contains S-component (a secretory component - glycoprotein with the molecular weight of $80 \mathrm{kDa}$ ). The molecular weight of the secretory $\operatorname{IgA}$ is $350 \mathrm{kDa}$ and more.

Immunoglobulin of class $\mathrm{M}$. The largest molecule of all Igs is a pentamer with the molecular weight of about $900 \mathrm{kDa}$. It contains about $5-10 \%$ of all serum Igs.

Class D immunoglobulin is a monomer with the molecular weight of $160 \mathrm{kDa}$. It accounts for about $0,2 \%$ of the total number of circulating Igs.

Class E immunoglobulin is a monomer with the molecular weight of $\approx 190 \mathrm{kDa}$. It accounts for about $0,002 \%$ of all circulating Igs.

The electrophoretic separation was carried out under the following conditions: 1) the test samples were treated with SDS to decompose the protein molecules into the separate peptide chains, they acquired the negative charge, which significantly exceeds the own charge of the protein molecule; 2) to study the protein mixture in the samples, the $8 \%$ distribution gel was prepared.

At the first stage of work, we studied the high molecular weight and low molecular weight peptides of the colostrum of Specimen 1, which were extracted and selected on the first day immediately after calving and after 12 hours (Fig. 2), and the high molecular weight peptides of the second day (samples taken 24 hours after calving). The high molecular weight peptides (No 25) and low molecular weight peptides (No 26) of milk (control) were used as reference samples.

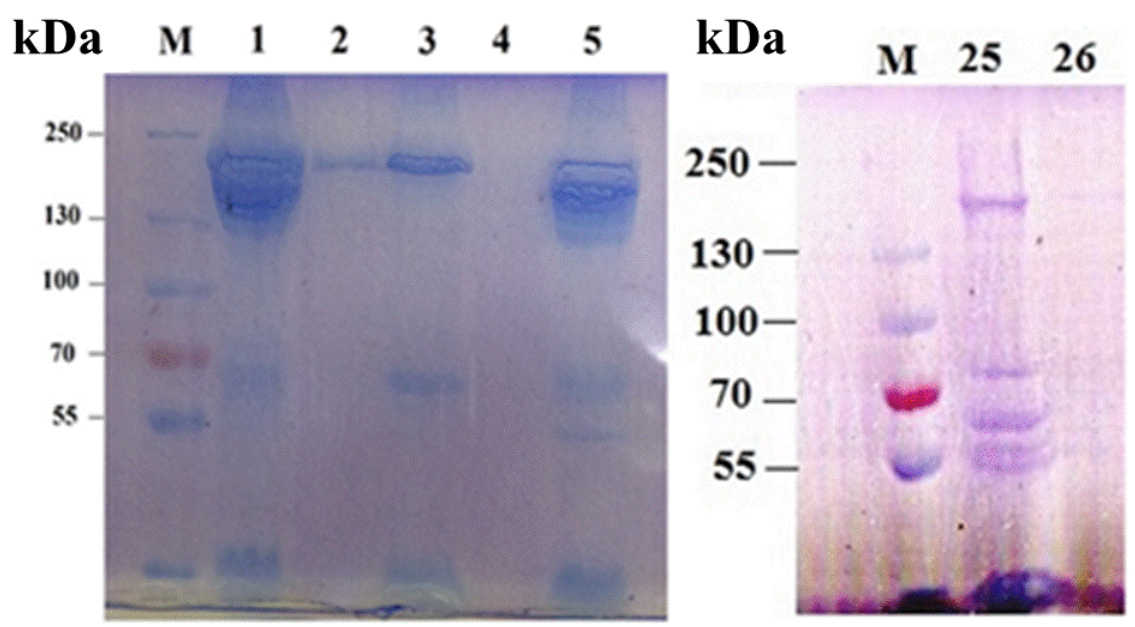

Figure 2. Electropherogram of the proteins of the colostrum of the first and second days after calving and cow milk

*Note. No 1-No 5 - the test samples of Specimen 1 of the colostrum of the first and second days after calving; No 25, 26 - the reference samples, high molecular weight and low molecular weight peptides respectively, extracted from milk (control); $\mathrm{M}$ - the protein markers of molecular weights: $250 \mathrm{kDa}$, $130 \mathrm{kDa}, 100 \mathrm{kDa}, 70 \mathrm{kDa}, 55 \mathrm{kDa}, 35 \mathrm{kDa}, 25 \mathrm{kDa}, 15 \mathrm{kDa}, 10 \mathrm{kDa}$. 
After the electrophoresis of the protein solutions of colostrum, four protein lines were determined in the electropherogram. Samples 1, 2, 3, 5, and 25 (reference sample) showed the lines that corresponded to the molecular weights of 160-190 kDa.

The weights typical for $\operatorname{IgG}$ and $\operatorname{IgA}(160 \mathrm{kDa}$ and $170 \mathrm{kDa}$, respectively). Samples 4 and 26 (reference sample) did not show any protein molecules.

Samples 1, 3, and 5 demonstrated the proteins with the molecular weight of $60 \mathrm{kDa}$, and Reference Sample 25 - the molecular weights of $55 \mathrm{kDa}, 60 \mathrm{kDa}$, and $80 \mathrm{kDa}$. On the basis of the obtained results, one can assume that the determined proteins can be IgG (55 $\mathrm{kDa})$ and $\mathrm{IgA}(62 \mathrm{kDa})$ heavy chains, and the proteins with the molecular weight of $80 \mathrm{kDa}$ can comprise a half of the Ig molecule which is composed of one heavy chain with the molecular weight of $55 \mathrm{kDa}$ and one light chain with the molecular weight of $25 \mathrm{kDa}$. Secretory component $\operatorname{sgA}(80 \mathrm{k} \mathrm{Da})$ and lactoferrin (the molecular weight of which is 80 $\mathrm{kDa})$ can also be possible.

At the second stage of work, we studied high molecular weight and low molecular weight peptides of the colostrum of Specimen 1, extracted and selected on the first and third days after calving (Figure 3). The reference samples represented high molecular weight (No 25) and low molecular weight (No 26) peptides of milk (control).

The obtained results demonstrate that high molecular weight peptide fractions No 7 , No 9, No 11, No 25 contain proteins with the molecular weight of 160-190 kDa. It corresponds to IgG and IgA, the molecular weight of which is $160 \mathrm{kDa}$ and $170 \mathrm{kDa}$, respectively. Protein molecules were not determined in low molecular weight peptide fractions No 6, No 8, No 10, No 12, and reference sample No 26. Sample 7, 9, 11 showed proteins with the molecular weight of $60 \mathrm{kDa}$. Reference Sample 25 demonstrated the presence of proteins with the molecular weight of $55 \mathrm{kDa}, 60 \mathrm{kDa}, 80 \mathrm{kDa}$.

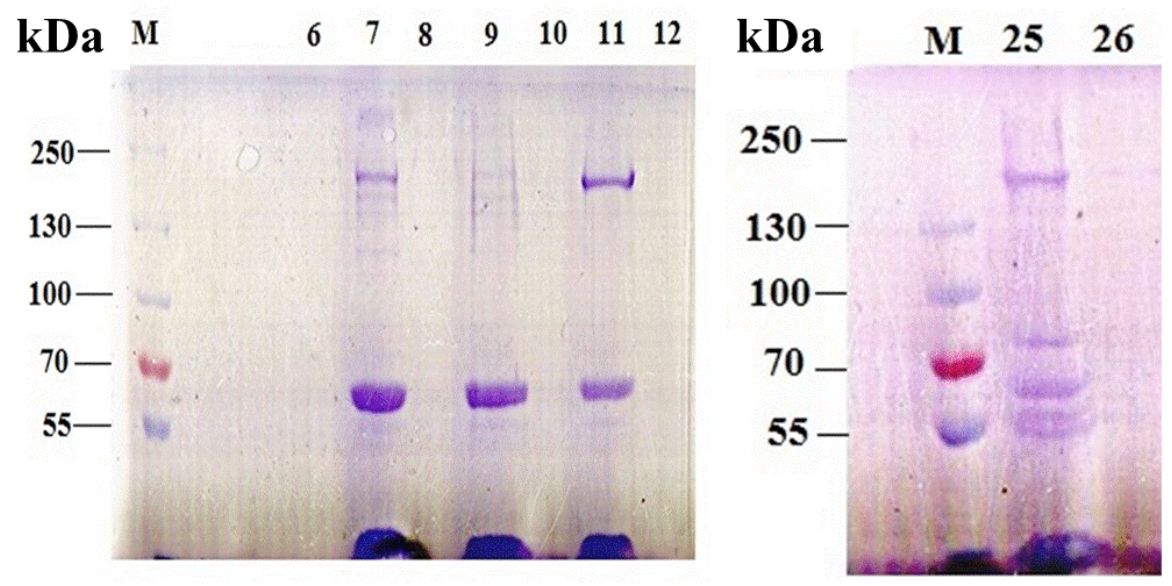

Figure 3. Electropherogram of the proteins of the colostrum of the second and third days after calving and bovine milk

*Note. No 6-No 12 - the test samples of the colostrum of Specimen 1 on the second and third days after calving; No 25, 26 - the reference samples, high molecular weight and low molecular weight peptides respectively, extracted from milk (control); $\mathrm{M}$ - the protein markers of molecular weights: $250 \mathrm{kDa}, 130 \mathrm{kDa}, 100 \mathrm{kDa}, 70 \mathrm{kDa}, 55 \mathrm{kDa}, 35 \mathrm{kDa}, 25 \mathrm{kDa}, 15 \mathrm{kDa}, 10 \mathrm{kDa}$. 
One can assume that the identified proteins can be $\operatorname{IgG}(55 \mathrm{kDa})$ and $\operatorname{IgA}(62 \mathrm{kDa})$ heavy chains. The protein molecules with the molecular weight of $80 \mathrm{kDa}$ can comprise a half of the Ig molecule, which is composed of one heavy chain with the molecular weight of $55 \mathrm{kDa}$ and one light chain with the molecular weight of $25 \mathrm{kDa}$. Secretory component sIgA ( $80 \mathrm{k} \mathrm{Da})$ and lactoferrin $(80 \mathrm{kDa})$ can also be possible.

At the third stage of work, we studied high molecular weight and low molecular weight peptides of the colostrum of Specimen 2 selected on the first day immediately after calving and 12 hours after calving and on the second day (Fig. 4). The reference samples represented high molecular weight (No 25) and low molecular weight (No 26) peptides of milk (control).

The electropherogram (Fig. 4) shows that Samples 13, 15, 16, 17, 19, 25 contain the lines similar to the molecular weights of 160-190 $\mathrm{kDa}$. According to published articles such molecular weights belong to the immunoglobulins of IgG and IgA classes $(160 \mathrm{kDa}$ and $170 \mathrm{kDa}$, respectively). Samples 14 and 18 did not show any presence of protein molecules.

Examining Samples 13, 15, 17, 19, the lines, which corresponded to the molecular weights of $60 \mathrm{kDa}$ and $55 \mathrm{kDa}$, were determined. Reference Sample 25 contains a line, which represents the molecular weight of $80 \mathrm{kDa}$. The identified proteins can represent $\mathrm{IgG}$ $(55 \mathrm{kDa})$ and $\operatorname{IgA}(62 \mathrm{kDa})$ heavy chains. The protein molecules with the molecular weight of $80 \mathrm{kDa}$ comprise a half of the Ig molecule, secretory component sIgA, and lactoferrin.

At the final stage of work, we studied the high molecular weight and low molecular weight peptides of the colostrum of Specimen 2, selected on the third day after calving, and the low molecular weight peptides, which were selected on the second day in 36 hours after calving (Fig. 5). The reference samples represented high molecular weight (No 25) and low molecular weight (No 26) peptides of milk (control).

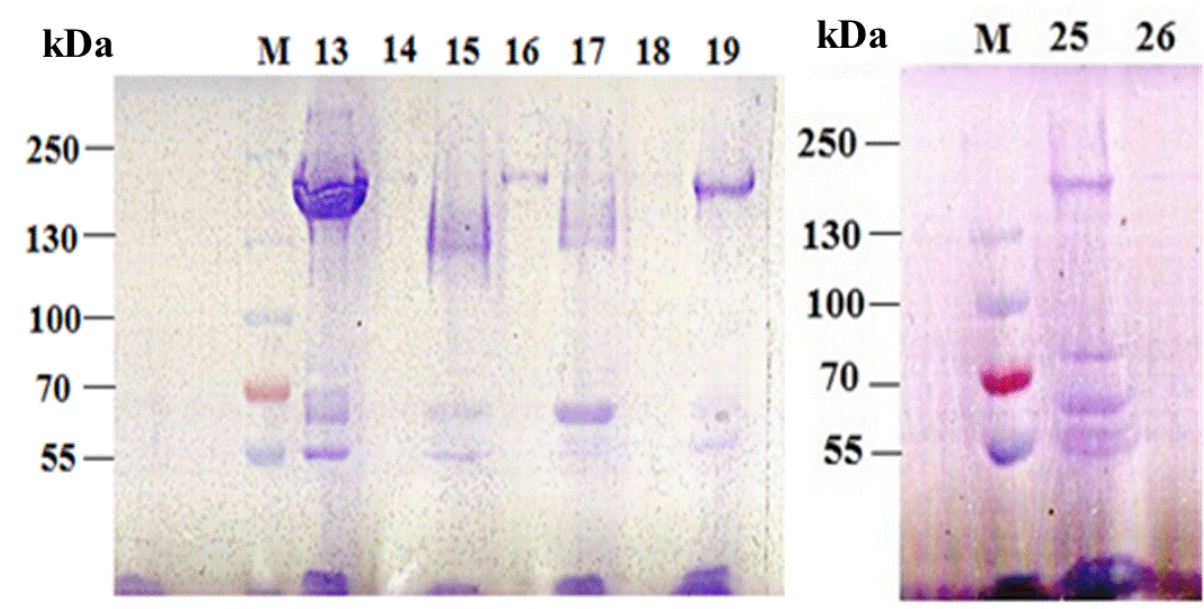

Figure 4. Electropherogram of the proteins of the colostrum of the first and second days after calving and cow milk

*Note. No13-No 19 - the test samples of Specimen 2 of the colostrum of the first and second days after calving; No 25, 26 - the reference samples, high molecular weight and low molecular weight peptides respectively, extracted from milk (control); $\mathrm{M}$ - the protein markers of molecular weights: $250 \mathrm{kDa}, 130 \mathrm{kDa}, 100 \mathrm{kDa}, 70 \mathrm{kDa}, 55 \mathrm{kDa}, 35 \mathrm{kDa}, 25 \mathrm{kDa}, 15 \mathrm{kDa}, 10 \mathrm{kDa}$. 


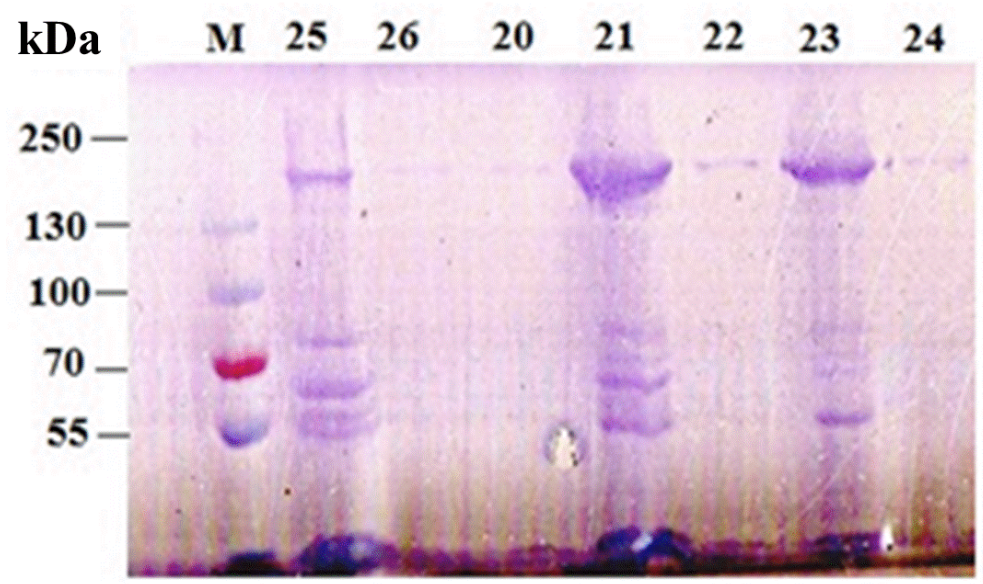

Figure 5. Electropherogram of the proteins of the colostrum of the second and third days after calving and cow milk

*Note. No20-No24 - the test samples of the colostrum of Specimen 2 of the second and third days after calving; No 25, 26 - the reference samples, high molecular weight and low molecular weight peptides respectively, extracted from milk (control); $M$ - the protein markers of molecular weights: $250 \mathrm{kDa}, 130 \mathrm{kDa}, 100 \mathrm{kDa}, 70 \mathrm{kDa}, 55 \mathrm{kDa}, 35 \mathrm{kDa}, 25 \mathrm{kDa}, 15 \mathrm{kDa}, 10 \mathrm{kDa}$.

According to the results of the electropherogram for Samples 20-24 and Reference Sample 25, the obtained lines match the molecular weights of 160-190 kDa. Such results indicate the presence of $\operatorname{IgG}$ and $\operatorname{IgA}$, the molecular weight of which is $160 \mathrm{kDa}$ and 170 $\mathrm{kDa}$, respectively.

The analysis of Samples 21, 23, 25 showed the presence of three lines of $60 \mathrm{kDa}, 55$ $\mathrm{kDa}$, and $80 \mathrm{kDa}$.

These results let assume that the lines with the molecular weights refer to the heavy chains $\operatorname{IgG}(55 \mathrm{kDa})$ and $\operatorname{IgA}(62 \mathrm{kDa})$, and the protein molecules with the molecular weight of $80 \mathrm{kDa}$ refer to a half of the molecule of immunoglobulin or secretory component $\operatorname{sIgA}(80 \mathrm{kDa})$, or lactoferrin $(80 \mathrm{kDa})$.

\section{Conclusions}

Thus, multifunctional content of colostrum makes it a promising raw material to develop diverse products of general and special purpose. Besides, from the practical point of view, only the colostrum selected on the first days after calving represents a special interest as, after a while, the level of proteins, namely, immunoglobulins, rapidly decreases in it.

The data above emphasize the relevance of the studies, selection and refinement of the high molecular weight biologically active protein fragments of colostrum for the purposes of its use in child nutrition, addition into milk powders. This will lead to the development and production of immuno-prophylactic products for maintaining immunity and preventing and reducing the occurrence of immunodeficiency states in the human body. 


\section{References}

1. Mohanty D., Mohapatra S., Misra S., Sahu P. (2016), Milk derived bioactive peptides and their impact on human health, Saudi Journal of Biological Sciences, 5, pp. 577583.

2. Sacerdote P. (2013), Biological components in a standardized derivative of bovine colostrum, Journal of Dairy Science, 96(3), pp. 1745-1754.

3. Karimova Sh., Iuldashev N., Ismailova G. (2015), Biokhimiia moloka, Uspekhi sovremennogo estestvoznaniia, 9(3), pp. 422-428.

4. Prosekov A., Kurbanova M. (2009), Analiz sostava i svoistv belkov moloka s tseliu ispolzovaniia $\mathrm{v}$ razlichnykh otrasliakh pishchevoi promyshlennosti, Tekhnika $i$ tekhnologiia pishchevykh proizvodstv, 4, pp. 68-71.

5. Sybirna N.O., Honchar M.V., Brodiak I.V. (2010) Khimiia bilka, Lviv.

6. Magdeldin S. (2012), Gel Electrophoresis, Principles and Basics.

7. Korhonen H. (2009), Bioactive components in bovine milk, Bioactive Components in Milk and Dairy Products, pp. 13-42.

8. Srinivas S., Prakash V. (2010), Bioactive Peptides from Bovine Milk a Casein: Isolation, Characterization and Multifunctional properties, International Journal of Peptide Research and Therapeutics, 16, pp. 7-15.

9. Walter L. Hurley, Peter K. Theil. (2011) Perspectives on immunoglobulins in colostrum and milk, Nutrients, 3, pp. 442-474.

10. Conte F., Scarantino S. (2013) A study on the quality of bovine colostrum: physical, chemical and safety assessment, Int. Food Research J, 20 (2), pp. 925-931.

11. Sacerdote P. (2013) Biological components in a standardized derivative of bovine colostrum, J. Dairy Science. 96 (3), pp. 1745-1754.

12. Madureira A.R., Tavares T., Gomes A.M.P. et al. (2010) Phisiological properties of bioactive peptides obtained from whey proteins, Journal of Dairy Science, 93 (2), pp. 437-455.

13. Korhonen H.J. (2013) Production and properties of health-promoting proteins and peptides from bovine colostrums and milk, Celluar and Molecular Biology, 59 (1), pp. $12-24$. 